Prepared in cooperation with the Indiana Department of Transportation

\title{
River Meander Modeling of the Wabash River near the Interstate 64 Bridge near Grayville, Illinois
}

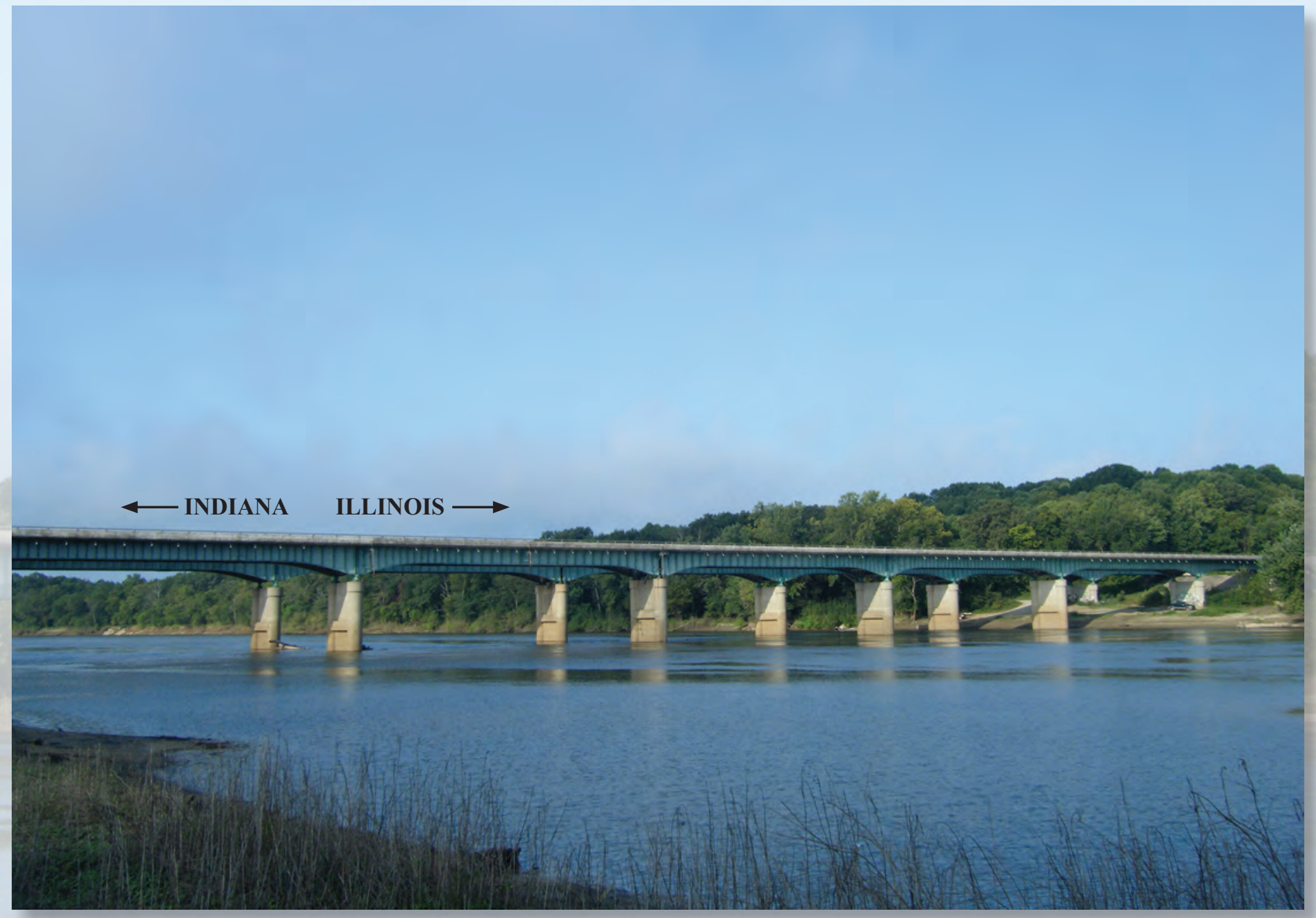

Scientific Investigations Report 2017-5117 
Cover. View of the Interstate 64 Bridge from the upstream left bank, August 18, 2015. (Photograph by Justin A. Boldt, U.S. Geological Survey.) 


\section{River Meander Modeling of the Wabash River near the Interstate 64 Bridge near Grayville, Illinois}

By Jeremiah G. Lant and Justin A. Boldt

Prepared in cooperation with the Indiana Department of Transportation

Scientific Investigations Report 2017-5117 


\title{
U.S. Department of the Interior \\ RYAN K. ZINKE, Secretary
}

\section{U.S. Geological Survey \\ William H. Werkheiser, Deputy Director exercising the authority of the Director}

\author{
U.S. Geological Survey, Reston, Virginia: 2018
}

For more information on the USGS - the Federal source for science about the Earth, its natural and living resources, natural hazards, and the environment—visit https://www.usgs.gov or call 1-888-ASK-USGS.

For an overview of USGS information products, including maps, imagery, and publications,

visit https://store.usgs.gov.

Any use of trade, firm, or product names is for descriptive purposes only and does not imply endorsement by the U.S. Government.

Although this information product, for the most part, is in the public domain, it also may contain copyrighted materials as noted in the text. Permission to reproduce copyrighted items must be secured from the copyright owner.

Suggested citation:

Lant, J.G., and Boldt, J.A., 2018, River meander modeling of the Wabash River near the Interstate 64 Bridge near Grayville, Illinois: U.S. Geological Survey Scientific Investigations Report 2017-5117, 12 p., https://doi.org/10.3133/sir20175117.

ISSN 2328-0328 (online) 


\section{Acknowledgments}

The authors wish to thank the Indiana Department of Transportation and the Illinois Department of Transportation. Special thanks are given to Kathryn Francis from the Indiana Department of Transportation for her assistance in ensuring a successful completion of the study. 



\section{Contents}

Acknowledgments ……...................................................................................................................

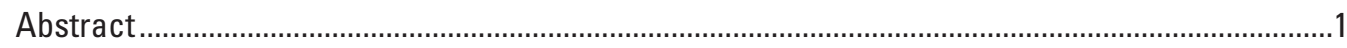

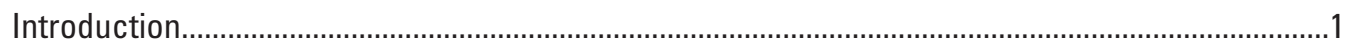

Meandering of the Wabash River ........................................................................................

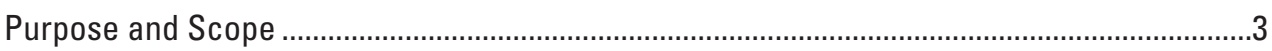

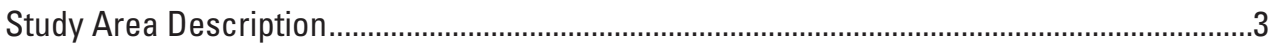

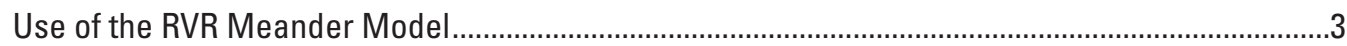

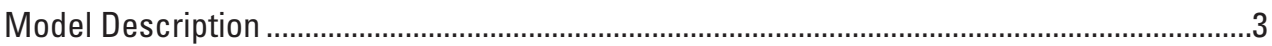

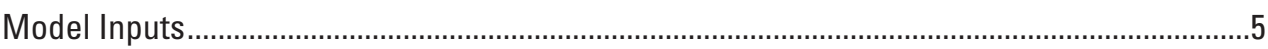

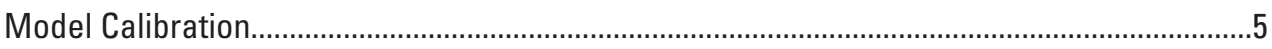

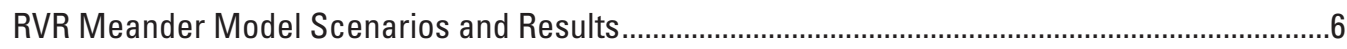

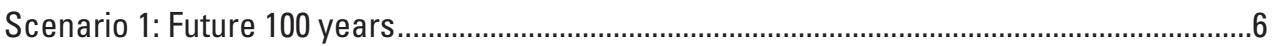

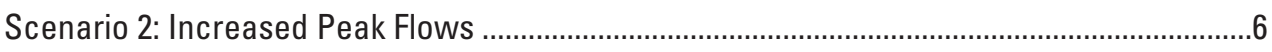

Scenario 3: Bank Armoring .................................................................................................

Model Sensitivity Analysis and Limitations ............................................................................10

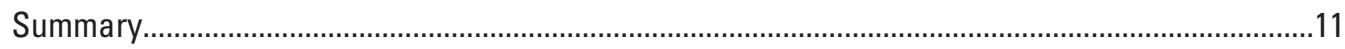

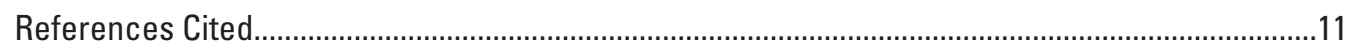

\section{Figures}

1. Google Earth imagery from 1998 and 2013, and photograph showing bank erosion along the right bank of the Wabash River about $0.25-0.40$ miles upstream of the

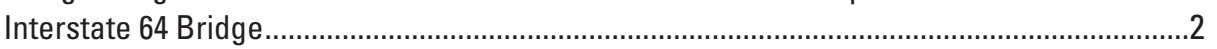

2. Map showing study area and river centerline for model input .......................................

3. Map showing RVR Meander output for scenario 1 showing migrated centerlines at 10-year increments ....................................................................................................

4. Map showing RVR Meander output for scenario 2 showing migrated centerlines at 10 -year increments ...............................................................................................

5. Map showing RVR Meander output for scenario 3 showing migrated centerlines

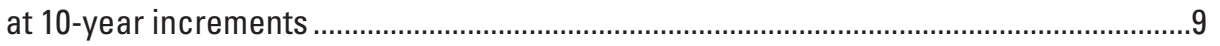

\section{Table}

1. Selected input parameters for the calibrated model .....................................................5 


\section{Conversion Factors}

U.S. customary units to International System of Units

\begin{tabular}{|c|c|c|}
\hline Multiply & By & To obtain \\
\hline \multicolumn{3}{|c|}{ Length } \\
\hline foot $(\mathrm{ft})$ & 0.3048 & meter $(\mathrm{m})$ \\
\hline mile (mi) & 1.609 & kilometer $(\mathrm{km})$ \\
\hline \multicolumn{3}{|c|}{ Area } \\
\hline square mile $\left(\mathrm{mi}^{2}\right)$ & 2.590 & square kilometer $\left(\mathrm{km}^{2}\right)$ \\
\hline \multicolumn{3}{|c|}{ Flow rate } \\
\hline cubic foot per second $\left(\mathrm{ft}^{3} / \mathrm{s}\right)$ & 0.02832 & cubic meter per second $\left(\mathrm{m}^{3} / \mathrm{s}\right)$ \\
\hline
\end{tabular}

International System of Units to U.S customary units

\begin{tabular}{lcc}
\hline \multicolumn{1}{c}{ Multiply } & By & To obtain \\
\hline meter $(\mathrm{m})$ & Length & foot $(\mathrm{ft})$ \\
\hline & 3.2808 & \\
\hline meter per second $(\mathrm{m} / \mathrm{s})$ & Speed & foot per second $(\mathrm{ft} / \mathrm{s})$ \\
\hline & 3.2808 & \\
\hline cubic meter per second $\left(\mathrm{m}^{3} / \mathrm{s}\right)$ & Flow rate & cubic foot per second $(\mathrm{ft} / \mathrm{s})$ \\
\hline & 35.31467 & \\
\hline Pascal $($ Pa) & Pressure & pound per square inch $(\mathrm{psi})$ \\
\hline & 0.000145 & \\
\hline Newton per cubic meter $\left(\mathrm{N} / \mathrm{m}^{3}\right)$ & Specific weight & pound-force per cubic foot $\left(\mathrm{lbf} / \mathrm{ft}^{3}\right)$ \\
\hline
\end{tabular}

\section{Datum}

Vertical coordinate information is referenced to (1) stage, the height above an arbitrary datum established at a streamgage, and (2) elevation, the height above the North American Vertical Datum of 1988 (NAVD 88).

Horizontal coordinate information is referenced to the North American Datum of 1983 (NAD 83). 


\title{
River Meander Modeling of the Wabash River near the Interstate 64 Bridge near Grayville, Illinois
}

\author{
By Jeremiah G. Lant and Justin A. Boldt
}

\section{Abstract}

Natural river channels continually evolve and change shape over time. As a result, channel evolution or migration can cause problems for bridge structures that are fixed in the flood plain. A once-stable bridge structure that was uninfluenced by a river's shape could be encroached upon by a migrating river channel. The potential effect of the actively meandering Wabash River on the Interstate 64 Bridge at the border with Indiana near Grayville, Illinois, was studied using a river migration model called RVR Meander. RVR Meander is a toolbox that can be used to model river channel meander migration with physically based bank erosion methods. This study assesses the Wabash River meandering processes through predictive modeling of natural meandering over the next 100 years, climate change effects through increased river flows, and bank protection measures near the Interstate 64 Bridge.

\section{Introduction}

River channels naturally tend to have sinuous patterns as they transport water downstream through a flood plain. The bends or curves in a river are called meanders. According to equilibrium theory, meanders form as a result of the river balancing a number of physical processes. More specifically, meanders form as soil erosion and deposition create more stable forms of the river through minimizing variability in planimetric geometry and hydraulic parameters of water depth, water velocity, and local channel slope (Langbein and Leopold, 1966). River meanders are a typical equilibrium form, but they tend to migrate. Migration can involve various types of movement such as translation, extension, rotation, and lobing and compound growth (Knighton, 1998). However, not all meandering rivers migrate, and sometimes certain reaches are more active than others. Meander bends can also cut off, either due to the development of a chute channel or through progressive narrowing of the meander neck due to channel migration, both of which can ultimately reroute the river, leaving the meander bend abandoned. The forms and processes of meandering rivers has been well-documented (Leopold and others, 1964; Yang, 1971; Ikeda and others, 1981; Leopold, 1994; Knighton, 1998, and Thorne, 2002).

River channels continually evolve and change shape over time, and natural river channel evolution or migration can cause problems for bridge structures that are fixed in the flood plain. At times, rivers can migrate in such a way that could weaken or threaten the stability of a bridge.

\section{Meandering of the Wabash River}

The Wabash River, near the border between Indiana and Illinois, is an actively meandering river that is crossed by Interstate 64 (I-64) near Grayville, Illinois. Recent bed and bank erosion activity in the vicinity of the I-64 Bridge (fig. 1), along with future planning discussions regarding the bridge, prompted an in-depth hydraulic study of the area. The objective of this study was to investigate the potential future impacts from meander migration of the Wabash River on the I-64 Bridge through a numerical modeling approach. The datasets used in this study are available through a data release at https://doi.org/10.5066/F70G3HWF (Boldt and Lant, 2018).

The Wabash River, as it was in 1816 when Indiana became a state, marked the boundary between Indiana and Illinois. The boundary began at the Wabash River mouth, which is at the confluence with the Ohio River, and continued along the middle of the river to a point approximately 10 miles (mi) southwest of Terre Haute, Indiana. The portion of the Wabash River that marks the state boundary between Indiana and Illinois is uncontrolled and actively migrating. However, even though the Wabash River has migrated and cut off over time, the state boundary has remained the same. As a result of these cutoffs, there are many locations where Indiana or Illinois now has land on the opposite side of the river. For example, the Wabash River meander that used to flow past Grayville, Ill., cutoff in 1985 (D. Ghere, Federal Highway Administration, written commun., 2015), which shortened the river by approximately $3.3 \mathrm{mi}$. The lower Wabash River has been the subject of numerous research studies over the years, including work by Jackson (1975, 1976), Shaver (1979), Konsoer (2014), and Zinger (2016). 


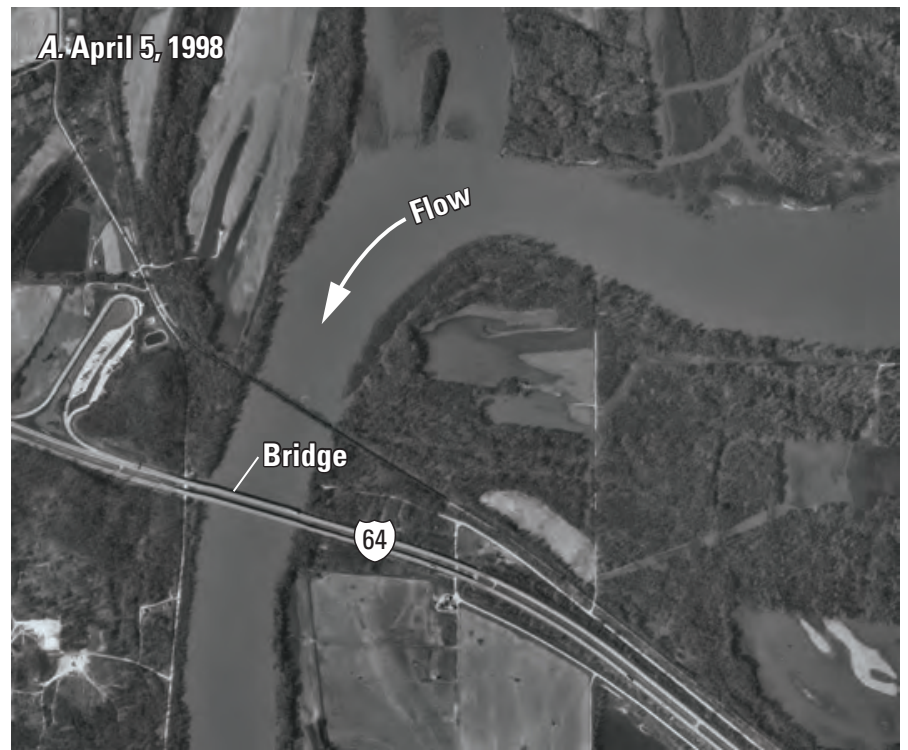

Base map from Google, 1998

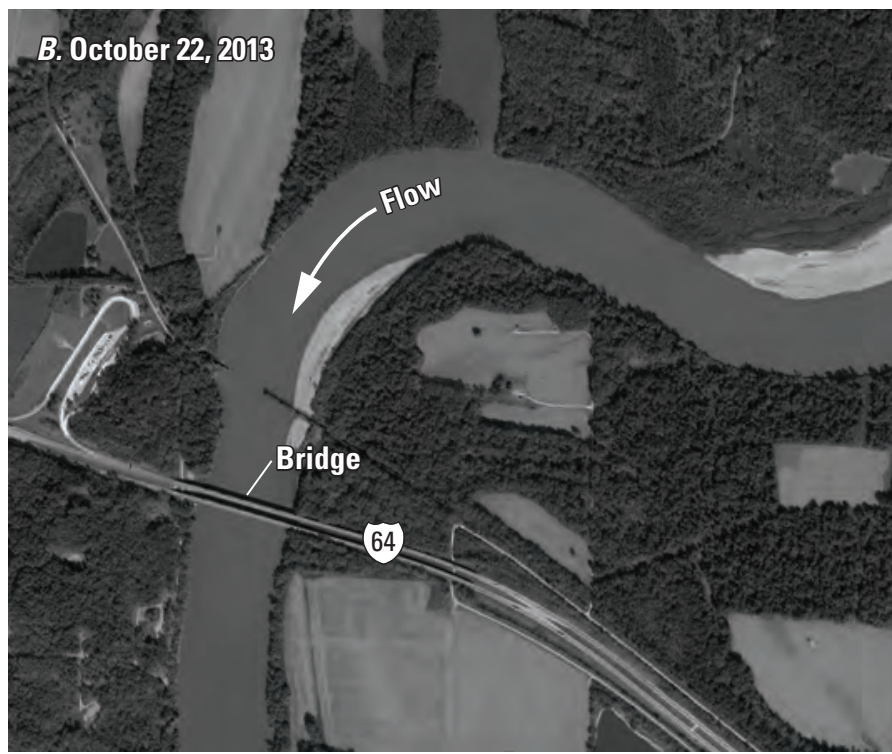

Base map from Google, 2013

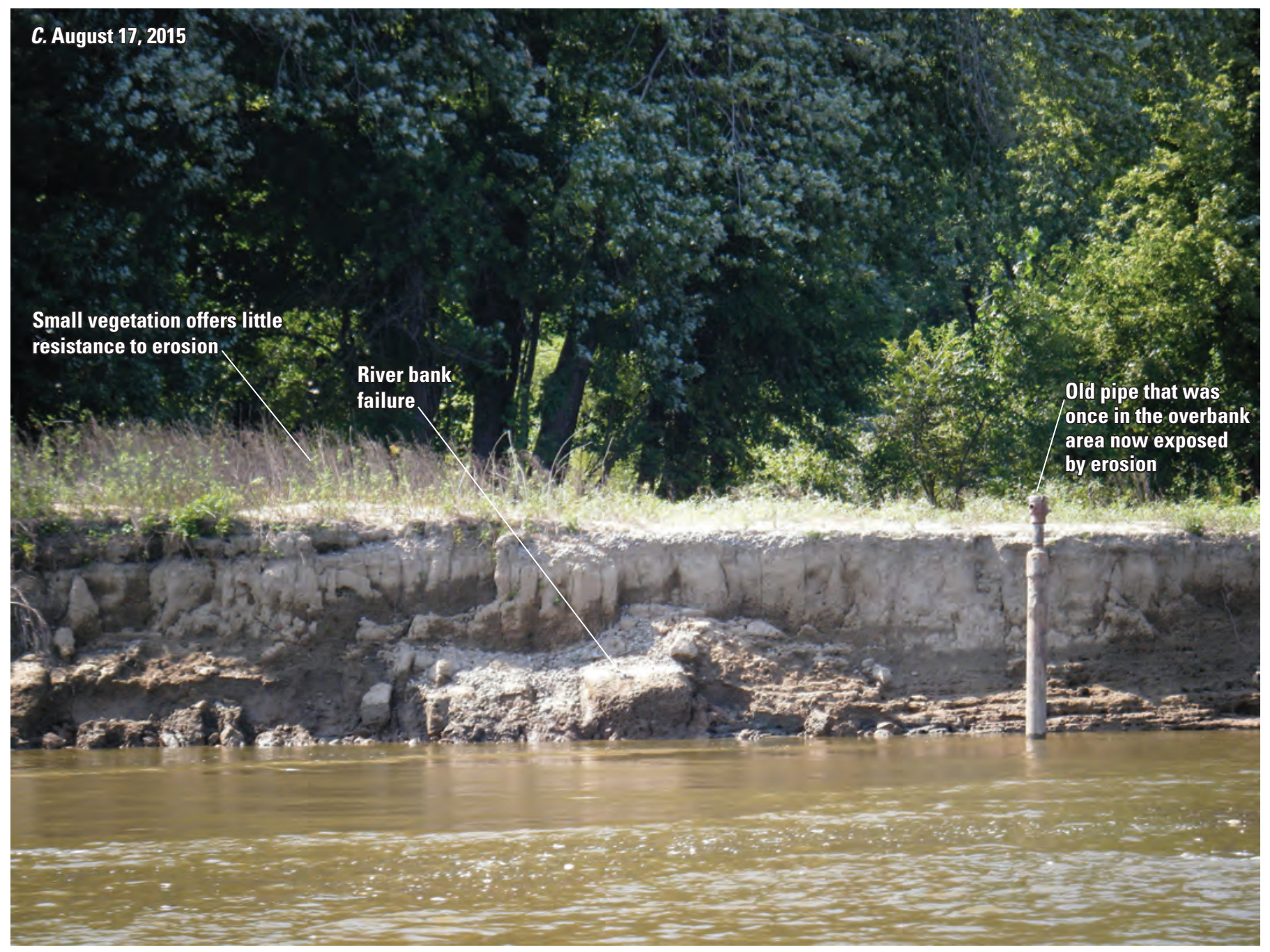

Figure 1. Google Earth imagery from $A, 1998$ and $B, 2013$. C, Bank erosion along the right bank of the Wabash River about $0.25-0.40$ miles upstream of the Interstate 64 Bridge. (Photo $C$ by J. Boldt, U.S. Geological Survey). 
The Indiana Department of Transportation (INDOT) and the Illinois Department of Transportation (IDOT) have annual meetings to discuss the status of projects on the border bridges that connect the two states. I-64 runs east-west through southern Indiana to southern Illinois, and the I-64 Bridge over the Wabash River is a set of twin structures that connect the states of Indiana and Illinois. The I-64 Bridge has been a priority topic in recent years due to a variety of structural and hydraulic concerns. INDOT and IDOT decided that an in-depth hydraulic study of the area was needed to better understand hydraulic conditions around the bridge and to help guide decisions for future planning. Two models were selected for development: a river meander model and a twodimensional hydraulic model. The site was also selected for a concurrent study to assess the I-64 Bridge's bridge scour countermeasures (Dudunake and others, 2017), which provided high-resolution bathymetry and terrestrial light detection and ranging data.

\section{Purpose and Scope}

The purpose of employing a river meander model and a two-dimensional hydraulic model was to gain a better understanding of the meandering processes and evolution of the Wabash River in relation to potential influence on a major bridge structure. The INDOT and the IDOT sought guidance and insight on how the Wabash River might migrate in the future and how it might impact the I-64 Bridge that connects both states. INDOT and IDOT were specifically interested in how a river meander model and a two-dimensional hydraulic model predict (1) natural meandering over the next 100 years, (2) climate change effects through increased river flows, and (3) the effect of bank protection measures upstream of the I64 Bridge. This report solely focuses on the development and results of the river meander model. The two-dimensional hydraulic model is presented in Boldt (2018).

\section{Study Area Description}

The Wabash River is the largest-flowing tributary of the Ohio River (Encyclopedia Britannica, 2016) and is approximately $500 \mathrm{mi}$ long. The Wabash River starts in western Ohio and generally flows west and southwest across Indiana until it nears the eastern border of Illinois. The river then turns south and approximately follows the state boundary between Indiana and Illinois for roughly $200 \mathrm{mi}$ until it drains into the Ohio River at the southwest corner of Indiana. The Wabash River is the longest free-flowing river east of the Mississippi River (Indiana Department of Natural Resources, n.d.), and it meanders freely in its own alluvium except in a few places where it encounters bedrock control (Jackson, 1976; Shaver, 1979).
The I-64 Bridge site crosses the Wabash River approximately 2 mi south by east of Grayville, Ill., and is part of the I-64 highway. I-64 crosses the Wabash River via parallel bridges, one for westbound traffic (upstream bridge) and the other for eastbound traffic (downstream bridge), with each bridge carrying two lanes of traffic. The original design plans were signed in 1964, and the construction of these bridges was completed in 1966.

The study area is an approximately $36-\mathrm{mi}$ reach of the Wabash River near Grayville, Ill. (fig. 2). Grayville, Ill., is located near the center of the study domain and is near where I-64 crosses the Wabash River. The study reach begins approximately $5 \mathrm{mi}$ downstream of Mount Carmel, Ill., and ends approximately $3 \mathrm{mi}$ downstream of New Harmony, Ind. The streamwise distance is $35.6 \mathrm{mi}$, and the straight-line distance is $19.0 \mathrm{mi}$. Most of the land contiguous to the study reach is either agricultural or forested.

\section{Use of the RVR Meander Model}

\section{Model Description}

A two-dimensional river meander migration model, RVR Meander (RVR Meander, 2011; Motta and others, 2012), was used to study and investigate future scenarios for the Wabash River within the study area. The most current version (2011) of RVR Meander contains the functionalities of a previous version of RVR Meander (Abad and Garcia, 2006) and a channel evolution model called CONCEPTS (Langendoen and Simon, 2008). The previous version of RVR Meander focused on modeling the planform migration of streams, and CONCEPTS focused on modeling sediment transport and bank erosion processes. The most current RVR Meander software was developed to be a toolbox for simulating long-term (engineering time scales) migration of meandering rivers on a reach-scale (Motta, 2013). The model has a stand-alone Windows-based interface and a geographic information system (GIS)-based interface through ArcGIS (Esri, 2010). RVR Meander has two methods for computing the river centerline migration: (1) a classic approach based on the near-bank excess velocity multiplied by a river migration coefficient and (2) a physically based approach where the physical processes involved in bank erosion are used. Bank erosion involves the processes of fluvial erosion and mass soil structure failure.

In this study, the physically based approach was used with the GIS-based interface using ArcGIS 10.0. The physically based approach was used because it is more advanced and more accurate than the classic approach, especially when modeling for longer periods (Motta and others, 2012). Instead of relating bank erosion to near-bank excess velocity, the 
$88^{\circ}-87^{\circ} 55^{\prime}-87^{\circ} 50^{\circ}$

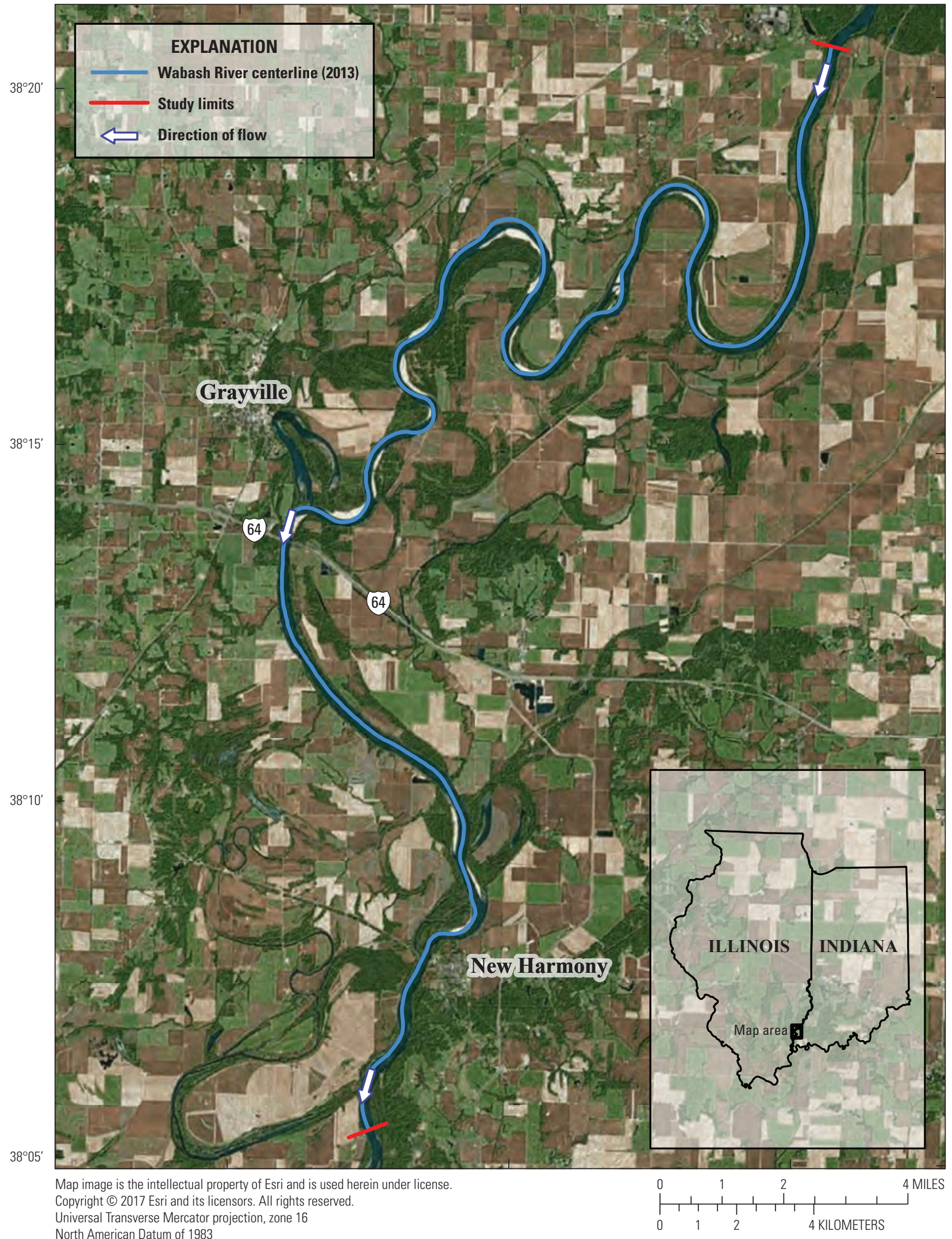

North American Datum of 1983

Figure 2. Study area and river centerline for model input. 
physically based approach is instead based on exceedance of a critical shear stress. The fluvial erosion rate, $E$, is defined by

$$
E=M\left(\frac{t}{t_{c}}-1\right)
$$

where

$$
\begin{aligned}
M & \text { is the erosion-rate coefficient, } \\
t & \text { is the shear stress acting on the bank, and } \\
t_{c} & \text { is the critical shear stress. }
\end{aligned}
$$

The erosion-rate coefficient and the critical shear stress are site-specific and can vary along the reach (Motta, 2013). Bank erosion processes are evaluated at each time step based on algorithms that calculate a minimum factor of safety based on force balance equations that account for the shear strength of the soil. Additionally, one of the objectives of this study was to analyze the effect of bank armoring (manufactured concrete structures or objects to stabilize and protect the river bank from erosion) along the right bank of the Wabash River north of the I-64 Bridge. The physically based modeling approach allows the specification of soil properties and bank erosion properties on a cross-sectional basis, which can also be used as a way to model the effect of localized bank armoring.

\section{Model Inputs}

The inputs to RVR Meander are a river centerline, a valley centerline, initial bank geometry on a cross-sectional basis (left and right bank profiles), and a variety of model parameters, which include bankfull discharge, bankfull width, channel slope, and physically based soil properties of the river banks, among others. Selected input parameters for the calibrated model are shown in table 1. RVR Meander also contains the ability to specify a number of computational and

\begin{tabular}{|c|c|}
\hline Model parameter & Value \\
\hline \multicolumn{2}{|c|}{ Hydraulic parameters } \\
\hline Bankfull flow & $2,000 \mathrm{~m}^{3} / \mathrm{s}$ \\
\hline Bankfull width & $300 \mathrm{~m}$ \\
\hline Initial channel slope & 0.00015 \\
\hline \multicolumn{2}{|c|}{ Soil parameters } \\
\hline Unit weight & $18,000 \mathrm{~N} / \mathrm{m}^{3}$ \\
\hline Erosion-rate coefficient & $3.0 \mathrm{E}-07 \mathrm{~m} / \mathrm{s}$ \\
\hline Critical shear stress & 6-20 Pa \\
\hline Cohesion & $5,000 \mathrm{~Pa}$ \\
\hline Angle of repose & $25 \mathrm{deg}$ \\
\hline
\end{tabular}

Table 1. Selected input parameters for the calibrated model.

$\left[\mathrm{m}^{3} / \mathrm{s}\right.$, cubic meter per second; $\mathrm{m}$, meter; $\mathrm{N} / \mathrm{m}^{3}$, Newton per cubic meter; $\mathrm{m} / \mathrm{s}$, meter per second; Pa, Pascal; deg, degree] hydrodynamic parameters, such as methods for bank shear stress and bank failure.

The river centerline was created from a recent (2013) Digital Elevation Model (DEM) in ArcGIS. The DEM was downloaded from The National Map (U.S. Geological Survey, 2016a), and the DEM has a resolution of 10 feet (ft). The centerline of the Wabash River was derived from bank lines that were extracted from the same DEM. The valley centerline was digitized in ArcGIS and is simply a line connecting the upstream and downstream points of the river centerline. The bankfull discharge was determined from statistical analysis of the annual peak flow record from the U.S. Geological Survey streamgage (station number 03377500) on the Wabash River at Mouont Carmel, Ill. (U.S. Geological Survey, 2016b). This is the nearest upstream gage and provides continuous discharge data for 90 years (1928-present) and annual peak discharge data for 137 years $(1875-1878,1885$-present). The data from the gage, along with drainage-area adjustments, were used to compute flood-frequency estimates for the bankfull conditions at the bridge. The bankfull discharge used in the model has an annual exceedance probability of approximately 0.90 and agrees with the flood stage as defined by the National Weather Service (2016). The bankfull width and channel slope were measured from the DEM. The cross-sectional data, which includes the initial bank geometry and soil properties, were equally spaced in the streamwise direction at approximately $445 \mathrm{ft}$. An idealized bed profile is determined by the model for each cross section based on channel curvature. The various soil properties were taken from soil surveys completed in the area (Konsoer, 2014) and from soil-related literature (Selby, 1992). The soil properties that were found to have the most influence on the model results were critical shear stress and erosion-rate coefficients. A single soil layer was used for each bank profile, but there was streamwise variability in the soil properties based on the calibration process.

\section{Model Calibration}

The RVR Meander model for the Wabash River was calibrated by adjusting the soil parameters in the bank profiles so that a known historic river centerline run through the model matched a known recent river centerline. The historic river centerline that was used for calibration was from 1998. This year was selected because of the availability of satellite imagery and in order to calibrate to recent migration rates. Daily flow values from the Mount Carmel gage (U.S. Geological Survey, 2016b) were analyzed to determine if the 15-year calibration period (1998-2013) was statistically representative of the entire flow record. The values were determined to be similar. Then the historic centerline was derived from bank lines using geoprocessing tools in ArcGIS. The bank lines were digitized in Google Earth using historic imagery of the study area from 1998. To calibrate the model, the erosion-rate coefficient parameter was adjusted uniformly to get general agreement with the 1998 river centerline, and then the critical 
River Meander Modeling of the Wabash River near the Interstate 64 Bridge near Grayville, Illinois

shear stress parameter was adjusted for each cross section until the 1998 centerline migrated to the 2013 centerline. Calibration was decided upon by visually comparing the historic centerline to the recent (2013) centerline in ArcGIS. Once calibrated, the model was run for the three scenarios of interest.

Due to the history of cutoffs within this section of the Wabash River, an additional step was taken as a way to informally check the calibration. An old river centerline can be run through the model to check if the river actually migrates in such a way to replicate where an actual cutoff has occurred. However, this version of RVR Meander does not account for cutoffs, but in such a case, it is common to identify likely cutoff locations when two migrated centerlines are within a half channel width of each other (Motta, 2013). The Wabash River has old cutoffs near Grayville, Ill., and New Harmony, Ind. To help validate the calibrated model, a historic centerline from 1816 was used to see if cutoff locations could be identified. The centerline of the Wabash River in 1816 was part of the state boundary between Indiana and Illinois, so the historic river centerline was extracted from a spatial data file of state boundaries. The spatial data file of the state boundaries was the 2015 TIGER/Line Shapefiles from the U.S. Census Bureau (U.S. Census Bureau, 2015). The model results show that it correctly identified the cutoff locations near Grayville, Ill., and New Harmony, Ind. Although not a true validation in the sense that the modern centerline was replicated exactly, the correct identification of cutoff locations gives confidence in the model.

\section{RVR Meander Model Scenarios and Results}

The calibrated model was used to run three scenarios. The first scenario investigated the natural meandering of the Wabash River over the next 100 years (2013-2113). The second scenario predicted potential climate change effects on the meander migration of the Wabash River by increasing the model bankfull flow by 10 percent. The third scenario investigated how proposed bank armoring on the right bank of the Wabash River just north of the I-64 Bridge would influence the meandering pattern. Model outputs include one-dimensional shapefiles of the migrated centerlines at defined increments and two-dimensional values of hydraulic properties.

\section{Scenario 1: Future 100 years}

In the first model scenario, the calibrated model was run for 100 years into the future from 2013 to 2113. Overall, the model predicts that the I-64 Bridge will not be greatly impacted by the migration of the Wabash River over the next 100 years. The model results show that the channel migrates a fair amount in some meander bend sections and does not migrate much in the straighter sections (fig. 3).
Just downstream of the I-64 Bridge, the model predicts that the channel migrates approximately $40 \mathrm{ft}$ east over the next 100 years. Just upstream of the I-64 Bridge, in the vicinity of the existing streambank erosion, the model predicts that the channel migrates approximately $220-250 \mathrm{ft}$ west over the next 100 years. The portion of the river farther upstream, near where the Grayville, Ill., cutoff occurred, is estimated to migrate southward by approximately $1,750 \mathrm{ft}$ south over the next 100 years. This migration is in the direction of the I-64 abutment and embankment on the Indiana side.

\section{Scenario 2: Increased Peak Flows}

In the second model scenario, the calibrated model was again run for 100 years into the future but with a larger bankfull flow value. This simulates the potential effect of increased flooding and peak flows, whether due to climate change, land use change, reservoir operation change, or something else. Overall, the model predicts that the I-64 Bridge will not be greatly impacted by the migration of the Wabash River over the next 100 years. In this model run, the bankfull flow value from the first scenario was increased by 10 percent. Although analysis of the gage data shows an increasing trend, the 10 percent increase was selected as an arbitrary value with the goal of showing how meander migration can change due to increased flows. The river width remained the same constant value as in the first scenario. The model results show that the channel migration is very similar to the first scenario except with slightly increased migration distances (fig. 4). Just downstream of the I-64 Bridge, the model predicts that the channel migrates approximately $40 \mathrm{ft}$ east over the next 100 years. Just upstream of the I-64 Bridge, in the vicinity of the existing streambank erosion, the model predicts that the channel migrates approximately $230-260 \mathrm{ft}$ west over the next 100 years. The portion of the river farther upstream, near where the Grayville, Ill., cutoff occurred, is estimated to migrate southward by approximately $1,850 \mathrm{ft}$ over the next 100 years. This migration is in the direction of the I-64 abutment and embankment on the Indiana side.

\section{Scenario 3: Bank Armoring}

In the third model scenario, the calibrated model was again run for 100 years into the future but with an artificially small erosion-rate coefficient (1E-12 meter per second) within the armored bank section. This simulates the effect of proposed bank armoring on the right bank of the Wabash River from the I-64 Bridge to about 3,500 ft upstream. In the model, the simulation assumes that bank armoring will hold the bank in place and not have any other effect. Overall, the model predicts that the I-64 Bridge will not be greatly impacted by the migration of the Wabash River over the next 100 years. The model results show that not only is the channel migration prevented along the bank-armored section, but also the migration upstream and downstream of the bank armoring 


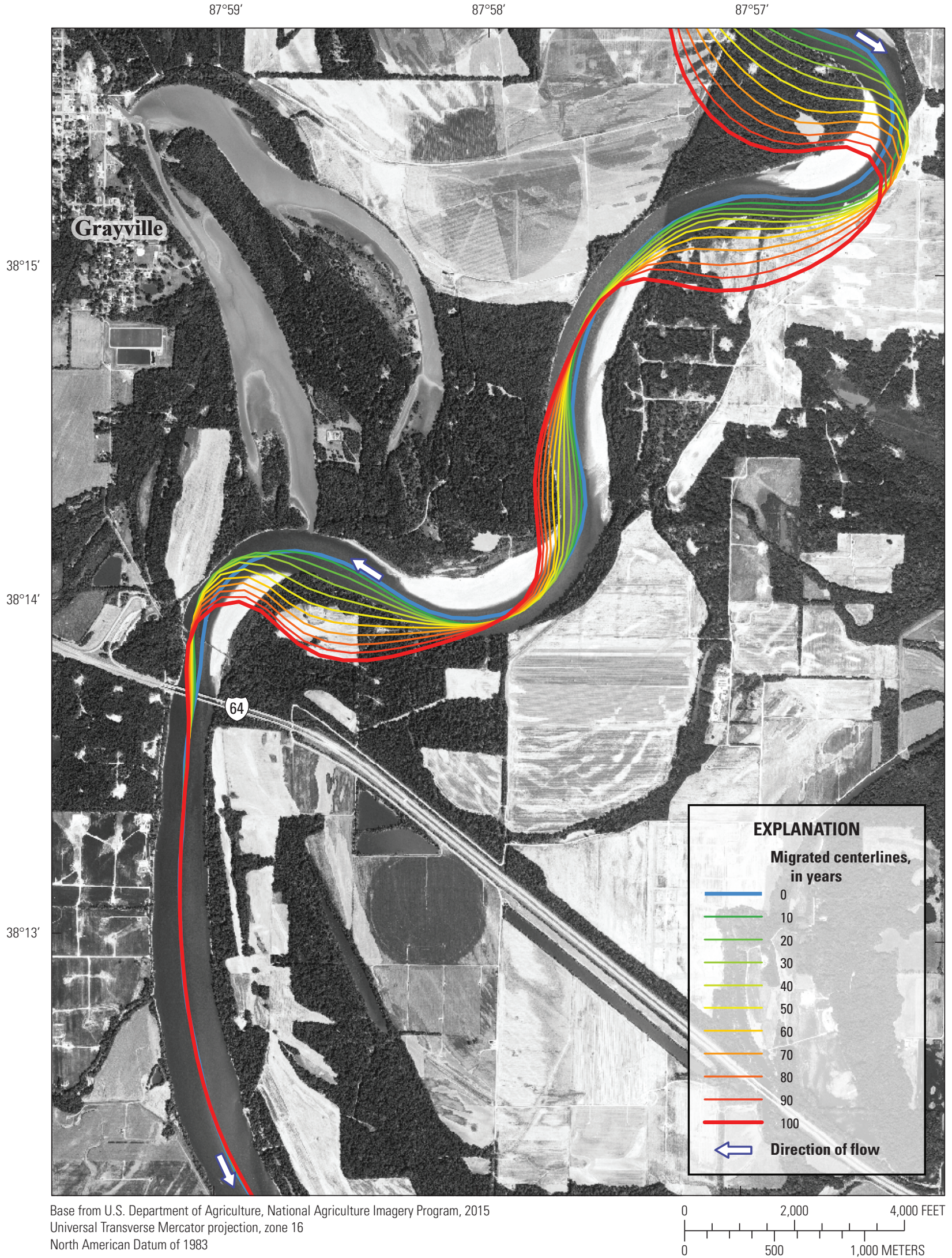

Figure 3. RVR Meander output for scenario 1 showing migrated centerlines at 10 -year increments. 


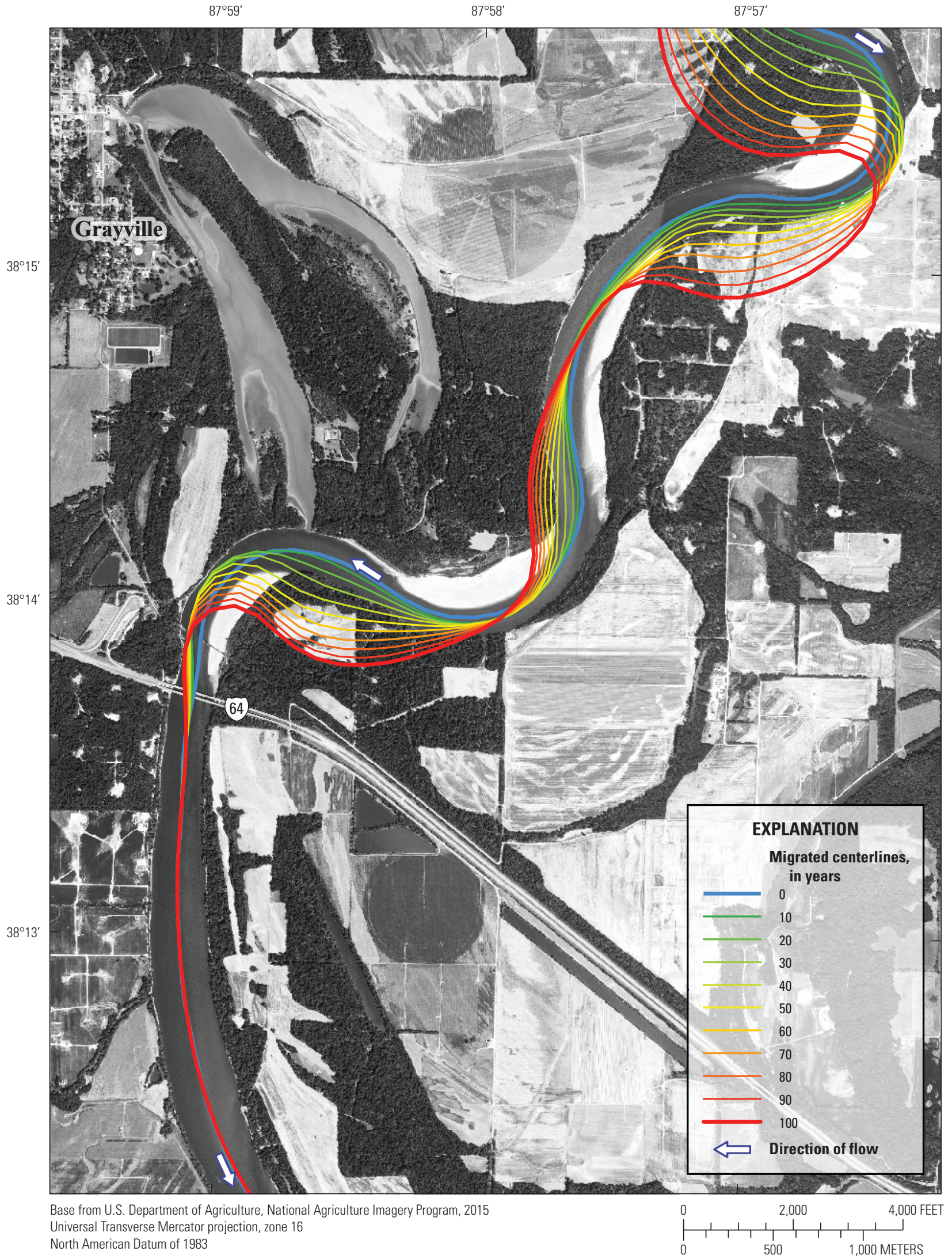

Figure 4. RVR Meander output for scenario 2 showing migrated centerlines at 10-year increments. 


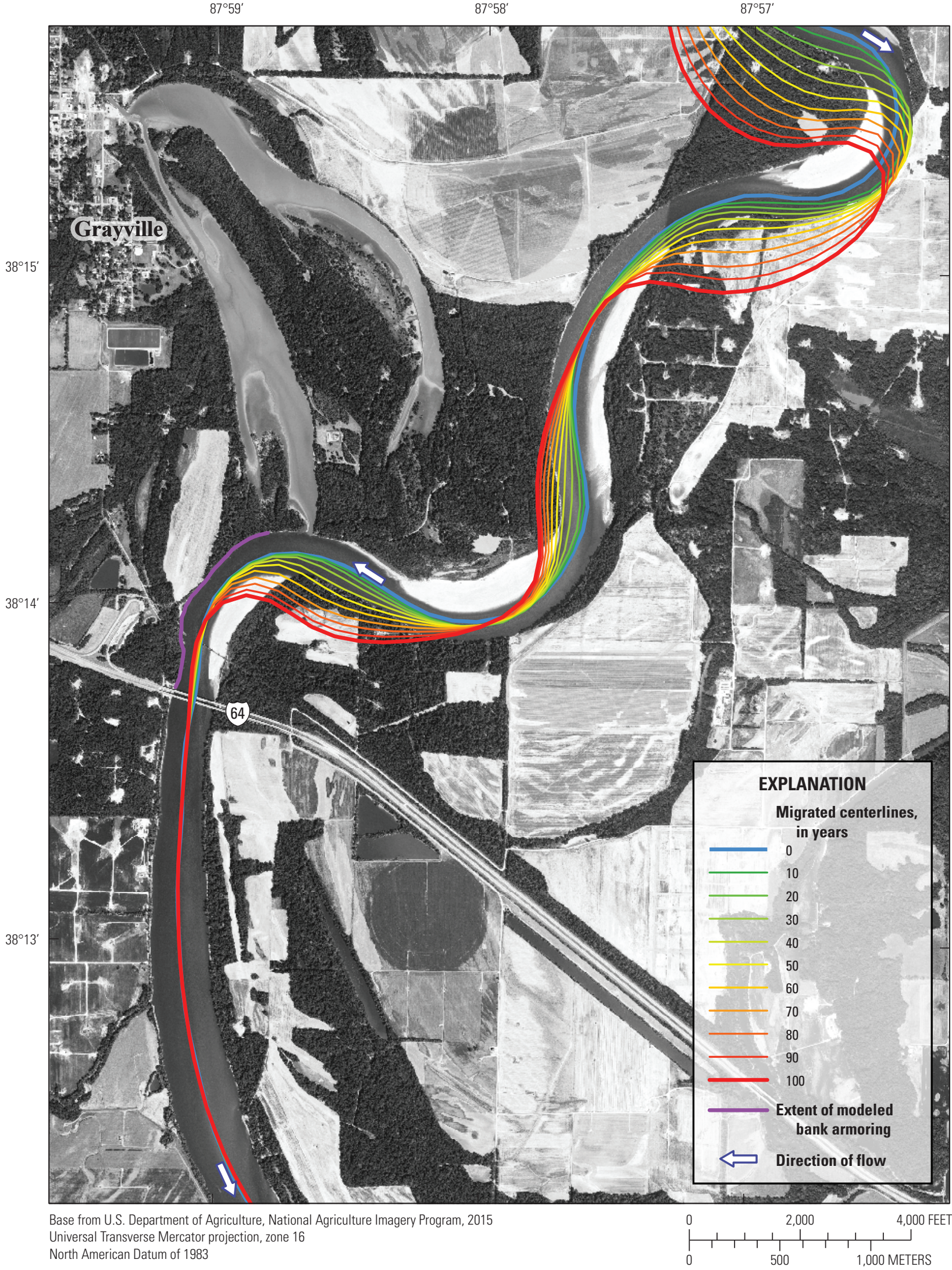

Figure 5. RVR Meander output for scenario 3 showing migrated centerlines at 10-year increments. 
section is reduced as compared to the first scenario (fig. 5). Just downstream of the I-64 Bridge, the model predicts that the channel migrates approximately $25 \mathrm{ft}$ east over the next 100 years, a reduction of 37 percent when compared to the scenario without bank armoring. The portion of the river farther upstream, near where the Grayville, Ill., cutoff occurred, is estimated to migrate southward by approximately $1,300 \mathrm{ft}$ over the next 100 years, a reduction of 26 percent when compared to the scenario without bank armoring. This migration is in the direction of the I-64 abutment and embankment on the Indiana side. The model shows slight migration (100-120 $\mathrm{ft}$ over the next 100 years) to the west in the section between the I-64 Bridge and the abandoned railroad bridge, but this is likely due to the finite distance required by the model for the high velocity core (the area of highest water velocities in a cross section) to cross over to the right bank, which increases as the upstream bend tightens. In reality, the shift is likely due to a combination of the growing point bar on the left bank thus shifting the thalweg to the west and increased shear stress values caused by the constriction of flow through the railroad bridge between the proposed bank armoring section and the point bar. In fact, a multibeam bathymetry survey in May 2016 revealed a large scour hole between and downstream of the sections of the failed railroad bridge, which is evidence of high erosional forces in this section (Dudunake and others, 2017).

\section{Model Sensitivity Analysis and Limitations}

The RVR Meander model was used to make predictions about the channel migration pattern of the Wabash River near Grayville, Ill., specifically immediately upstream and downstream of the I-64 Bridge. The model was calibrated using a historic centerline from 1998. The calibrated model was used to run three scenarios: (1) natural meandering over the next 100 years (2013-2113), (2) climate change effects through increased river flows, and (3) the effect of bank protection measures upstream of the I-64 Bridge. The model results for all three scenarios indicate that the I-64 Bridge will not be threatened by meander migration over the next 100 years. Additionally, the model results indicate that the proposed bank armoring may prevent future streambank erosion along that section as well as reduce the magnitude of meander migration upstream and downstream of the bank armoring section. These findings could provide insight to those making planning decisions about the future of the I-64 Bridge. However, the model results are an estimate and are specific to the RVR Meander model, which is just one of several channel migration models.

In order to help quantify the uncertainties associated with the RVR Meander model, a rudimentary sensitivity analysis was conducted. In each of the sensitivity analysis runs, a single parameter was changed at a time, and Scenario 1 was considered the baseline for comparison purposes. The parameters which need to be tested for sensitivity are the bankfull flow and the soil properties. To assess the bankfull flow parameter, Scenario 2 can be used as a sensitivity analysis as the only change was increasing the flow by 10 percent, and those results were presented in "Scenario 2: Increased Peak Flows." For the second parameter, the first model scenario was rerun with different soil properties. The first rerun decreased the critical shear stress everywhere by 10 percent, and the second rerun increased the erosion-rate coefficient everywhere by 33 percent. Both of these had very similar results, with the change in critical shear stress having a stronger effect, meaning an increase in centerline migration as reported next. Just downstream of the I-64 Bridge, the model predicts that the channel migrates approximately $40 \mathrm{ft}$ east, no change from the baseline condition, over the next 100 years. Just upstream of the I-64 Bridge, in the vicinity of the existing streambank erosion, the model predicts that the channel migrates approximately 260-290 ft west, an increase of $40 \mathrm{ft}$ from the baseline condition, over the next 100 years. The portion of the river farther upstream, near where the Grayville, Ill., cutoff occurred, is estimated to migrate southward by approximately $2,000 \mathrm{ft}$, an increase of $250 \mathrm{ft}$ from the baseline condition, over the next 100 years. As the sensitivity analysis shows, the model is more sensitive to changes in soil properties than it is to changes in flow. Variability in soil properties can be expected, so this analysis helps quantify the uncertainty in the model results.

Because the bend immediately upstream of the I-64 Bridge is of primary concern, it warrants some additional discussion. Over time, the simulations show that the bend of concern is continually tightening its curvature (decreasing the centerline radius of curvature). During periods of overbank flow, the region on the inside of the bend may become more of a preferred flow path as the radius decreases, which could eventually result in the formation of a new cutoff. Although RVR Meander does not allow for this cutoff process to be modeled, it can still be used to predict potential cutoff locations. One way to quantify how this bend is predicted to change over time and its associated risk is by looking at the ratio of the radius to width $(\mathrm{r} / \mathrm{w})$ of the river. Leopold and Wolman (1960) found that most river meanders tend to have a r/w value between 2 and 3. RVR Meander has a built-in Curvature Evaluation Tool to help quantify $r / w$ values. At the start of the simulation (year 0 ), this bend has a $\mathrm{r} / \mathrm{w}$ value of 1.6 , which means this bend is already tighter than the majority of natural river meanders, and the $\mathrm{r} / \mathrm{w}$ value is less than 1.0 by year 36 . Although the $\mathrm{r} / \mathrm{w}$ value does not indicate when a cutoff may occur, it does show increasing risk over time. The region on the inside of the bend is heavily forested, which provides more stability than other land use types, but it should be monitored over time and especially during flood flows.

There are limitations to the RVR Meander model. First, the two-dimensional model itself is a simplified version of reality, through the use of, for example, a constant water discharge, no bed aggradation or degradation, and a constant channel width. Although a physically based method for bank erosion is much improved over a migration coefficient, it still 
does not completely capture all of the physics involved in bank erosion. Researchers are continuing to improve numerical modeling of river morphodynamics (Limaye and Lamb, 2014; Langendoen and others, 2016; Bogoni and others, 2017). Additionally, although this version of the model cannot model the cutoff processes, neck cutoffs can still be predicted by looking at the characteristics of the migrated centerlines, and no cutoffs were predicted for the scenarios modeled. Second, the soil properties were considered to be one representative, homogeneous layer for each bank profile, and although the model included streamwise variability in the soil parameters, there was no flood plain soil heterogeneity as part of the model. This is primarily due to the limited availability of such data. Güneralp and Rhoads (2011) and Motta (2013) showed that flood plain soil complexity is related to migratedcenterline variability and planform complexity. Although areas of bedrock control were not specifically defined, they were accounted for to a fair extent in the soil properties during the model calibration process. Finally, this model is based on the constant application of the specified parameters. Any natural or man-made perturbation could alter the results. For example, the frequency and timing of major flood events, streambank modification, or an unexpected local change in soil properties could cause a local perturbation that may then get exacerbated over time. However, given these limitations, this river meander model is still incredibly useful for providing insight into future river meander scenarios and helping to guide planning decisions. The results presented should be combined with close monitoring in the future.

\section{Summary}

This study investigated the future potential impacts of the Wabash River on the Interstate 64 (I-64) Bridge by means of a river meander model called RVR Meander. The scenarios that were modeled considered (1) natural meandering over the next 100 years (2013-2113), (2) climate change effects through increased river flows, and (3) bank protection measures near the I-64 Bridge. The datasets used in this study are available through a data release at https://doi.org/10.5066/ F70G3HWF (Boldt and Lant, 2018). The Wabash River has historically been a very actively migrating river, and the RVR Meander model predicts that it will continue to be in the future. It is important to keep in mind that different meander bends migrate at various rates depending on a number of physical factors. The two main areas of risk are the continued bank erosion to the west and the continued tightening of the first meander upstream of the I-64 Bridge. The results of the model showed that the I-64 Bridge does not currently appear to be impacted by any of the future scenarios that were modeled. Given the major bank erosion that has been occurring just upstream of the I-64 Bridge, especially in the past $10-12$ years, diligent monitoring and re-evaluation are important for the future.

\section{References Cited}

Abad, J.D., and Garcia, M.H., 2006, RVR Meander: A toolbox for re-meandering of channelized streams: Computers \& Geosciences, v. 32, no. 1, p. 92-101.

Bogoni, Manuel, Putti, Mario, and Lanzoni, Stefano, 2017, Modeling meander morphodynamics over self-formed heterogeneous floodplains: Water Resources Research, v. 53, p. 5137-5157.

Boldt, J.A., 2018, Development of a hydraulic model and flood-inundation maps for the Wabash River near the Interstate 64 Bridge, Illinois: U.S. Geological Survey Scientific Investigations Report 2017-5140, 13 p., https://doi.org/10.3133/sir20175140.

Boldt, J.A., and Lant, J.G., 2018, Geospatial output data from the RVR Meander model of the Wabash River near the Interstate 64 Bridge near Grayville, Illinois: U.S. Geological Survey data release, https://doi.org/10.5066/ F70G3HWF.

Dudunake, T.J., Huizinga, R.J., and Fosness, R.L., 2017, Bridge scour countermeasure assessments at select bridges in the United States, 2014-16: U.S. Geological Survey Open-File Report 2017-1048, 10 p., accessed September 13, 2017, at https://doi.org/10.3133/ofr20171048.

Encyclopedia Britannica, 2016, Wabash River, accessed October 2016 at https://www.britannica.com/place/ Wabash-River.

Esri, 2010, ArcGIS, accessed June 2016 at http:/www.esri.com/software/arcgis/.

Güneralp, İnci, and Rhoads, B.L., 2011, Influence of flood plain erosional heterogeneity on planform complexity of meandering rivers: Geophysical Research Letters, v. 38, no. 14, L14401, accessed September 13, 2017, at https://doi.org/10.1029/2011GL048134.

Ikeda, Syunsuke, Parker, Gary, and Sawai, Kenji, 1981, Bend theory of river meanders. Part 1. Linear development: Journal of Fluid Mechanics, v. 112, p. 363-377.

Indiana Department of Natural Resources, n.d., Facts about Wabash River and Sugar Creek: Indiana Department of Natural Resources Fact Sheet, 2 p., accessed September 13, 2017, at http://www.in.gov/dnr/files/WabashRiverFacts.pdf.

Jackson, R.G., 1975, Velocity-bed-form-texture patterns of meander bends in the lower Wabash River of Illinois and Indiana: Geological Society of America Bulletin, v. 86, no. 11, p. 1511-1522. 
Jackson, R.G., 1976, Depositional model of point bars in the lower Wabash River: Journal of Sedimentary Petrology, v. 46, no. 3, p. 579-594.

Konsoer, K.M., 2014, Influence of riparian vegetation on nearbank flow structure and rates of erosion on a large meandering river: Urbana-Champaign, University of Illinois, $\mathrm{PhD}$ dissertation, $236 \mathrm{p}$.

Knighton, David, 1998, Fluvial Forms and Processes: A New Perspective: Arnold, London, 383 p.

Langbein, W.B., and Leopold, L.B., 1966, River MeandersTheory of Minimum Variance: U.S. Geological Survey Professional Paper 422-H, p. H1-H15 [also available at https://pubs.er.usgs.gov/publication/pp422H].

Langendoen, E.J., and Simon, Andrew, 2008, Modeling the evolution of incised streams. II: Streambank erosion: Journal of Hydraulic Engineering, v. 134, no. 7, p. 905-915, accessed September 13, 2017, at https://doi.org/10.1061/ (ASCE)0733-9429(2008)134:7(905).

Langendoen, E.J., Mendoza, Alejandro, Abad, J.D., Tassi, Pablo, Wang, Dongchen, Ata, R. Abderrezzak, K.E., and Hervouet, J.M., 2016, Improved numerical modeling of morphodynamics of rivers with steep banks: Advances in Water Resources, v. 93, no. A, p. 4-14.

Leopold, L.B., 1994, A view of the river: Harvard University Press, Cambridge, Massachusetts, 320 p.

Leopold, L.B., and Wolman, M.G., 1960, River meanders: Bulletin of the Geological Society of America, v. 71, no. 6, p. 769-794.

Leopold, L.B., Wolman, M.G., and Miller J.P., 1964, Fluvial processes in geomorphology: W. H. Freeman and Company, San Francisco, CA, 522 p.

Limaye, A.B.S., and Lamb, M.P., 2014, Numerical simulations of bedrock valley evolution by meandering rivers with variable bank material: Journal of Geophysical Research Earth Surface, v. 119, p. 927-950.

Motta, Davide, Abad, J.D., Langendoen, E.J., and Garcia, M.H., 2012, A simplified 2D model for meander migration with physically-based bank evolution: Geomorphology, v. $163-164$, p. 10-25.
Motta, Davide, 2013, Meander migration with physicallybased bank erosion: Urbana-Champaign, University of Illinois, PhD dissertation, 207 p.

National Weather Service, 2016, Advanced Hydrologic Prediction Service, Wabash River at Mount Carmel (MCRI2), accessed June 2016, at http://water.weather.gov/ahps2/ hydrograph.php?wfo=ind\&gage=MCRI2.

RVR Meander, 2011, River meander migration software, accessed June 2016, at http://www.rvrmeander.org/ software.html.

Selby, M.J., 1992, Hillslope materials and processes: Oxford University Press, New York, 480 p.

Shaver, R.H., 1979, Geologic story of the lower Wabash valley with emphasis on the New Harmony area: Department of Natural Resources Geological Survey Occasional Paper 27, $14 \mathrm{p}$.

Thorne, C.R., 2002, Geomorphic analysis of large alluvial rivers: Geomorphology, 44, p. 203-219.

U.S. Census Bureau, 2015, TIGER/Line Shapefiles, accessed July 2016 at ftp://ftp2.census.gov/geo/tiger/TIGER2015/ COUNTY/.

U.S. Geological Survey, 2016a, The National Map, accessed February 2016 at http://nationalmap.gov/elevation.html.

U.S. Geological Survey, 2016b, USGS 03377500, Wabash River at Mt. Carmel, Illinois: U.S. Geological Survey, accessed June 2016 at https://nwis.waterdata.usgs.gov/il/ nwis/uv/?site no $=03377500$.

Yang, C.T., 1971, On river meanders: Journal of Hydrology, v. 13, p. $231-253$.

Zinger, J.A., 2016, From meander bend to oxbow lake: morphodynamics and sedimentology of chute cutoffs: UrbanaChampaign, University of Illinois, PhD dissertation, 384 p. 
For more information about this publication, contact Director, Ohio-Kentucky-Indiana Water Science Center U.S. Geological Survey

9818 Bluegrass Parkway

Louisville, KY 40299

For additional information visit https://ky.water.usgs.gov/

Publishing support provided by the

Madison and Rolla Publishing Service Centers 


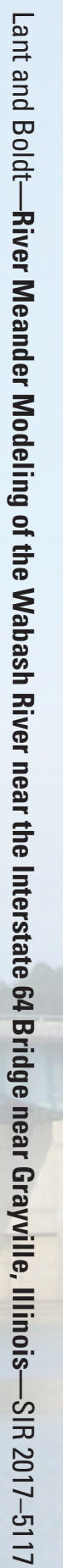

